\title{
Citizenship with a price tag: the law and ethics of investor citizenship programmes
}

\author{
Jelena DZankic*
}

European University Institute

\begin{abstract}
$\underline{\text { Abstract }}$
While a significant amount of attention has been paid in scholarly work to the modes of acquisition of citizenship at birth, either through territorial attachments (1us soli) or descent (Ius sanguinis), far less consideration has been given to the acquisition of citizenship after birth (1us nexi). Even if the notion of ius nexi encapsulates a variety of modes for the acquisition of citizenship through connection to the host state, the one that has recently gained salience in the context of the preferential naturalisation of investors is that of ius pecuniae - i.e. citizenship acquisition driven by money. Although setting a price tag on membership in a community is intuitively disquieting, there has bitherto been little discussion as to why this might be the case. The primary goal of this article is to set out three sets of criteria against which the different mechanisms of preferential naturalisation of investors can be evaluated.

Deploying a critique of the notion of 'genuine ties', we first examine whether the economic utility of the investment to the state can suffice to override some or all other criteria for naturalisation. Then, we look at the preferential treatment of investors in the context of merit-based naturalisation. Finally, we examine how the investment-based ius pecuniae affects the relationship between the members of the polity and naturalised investors and between naturalised investors and other applicants subject to ordinary naturalisation. The analysis suggests that, even though all these criteria have pitfalls, the principle that citizenship should instantiate a claim of equality best explains why we are uncomfortable with the idea of selling citizenship.
\end{abstract}

Keywords: citizenship; investment; facilitated naturalisation; equality; discretion.

The exploration of citizenship, the link between the individuals and the state, has been a 1 quest that has engaged legal scholars, political scientists, sociologists, anthropologists and demographers. Indeed, having at its heart the reciprocal relationship between the individual and the state, citizenship not only helps to describe the rights and duties which stem from an individual's membership of a polity, ${ }^{1}$ but also how that very membership has

* Acknowledgments: this article is the first in the series of publications stemming from my broader research on investor citizenship programmes. An earlier version of the article was published as a RSCAS/EUDO Working Paper at the European University Institute (EUI) in Florence. I am particularly grateful to Professor Rainer Bauböck, Professor Jo Shaw and Dr Oleg Korneev for their comments and suggestions, as well as to my colleagues from the Migration Working Group at the EUI.

1 Hannah Arendt, The Origins of Totalitarianism (Harcourt Brace Jovanovich 1951) 294; T H Marshall, 'Citizenship and Social Class' in Jeff Manza and Michael Sauder (eds), Inequality and Society (Norton \& Co 2009) $148-54$. 
been constructed. In the form of 'nationality', recognised in national and international law, the ascription of membership status is the sole prerogative of sovereign states. Individuals can gain access to a state's citizenship either at birth (which happens automatically), or after birth (by various forms of registration or naturalisation). The two modes of acquisition of citizenship at birth - through territorial attachments (ius soli) or descent (ius sanguinis) - have received considerable attention in the work of both legal scholars and political scientists. ${ }^{2}$ Far less academic focus has been directed towards the acquisition of citizenship after birth (ius nexi). The attraction of studying citizenship acquisition after birth is the task of exploring the variety of functional grounds established by states for permitting, or in some cases facilitating, access to citizenship by non-citizens. ${ }^{3}$ One of the functional grounds for facilitated naturalisation, the one that has recently gained salience in the public sphere, is the granting of preferential treatment to investors in the process of acquisition of citizenship (ius pecuniae).

The application of ius pecuniae as the functional grounds for the admission of individuals in a polity has amplified with the spread of the global economic crisis, which enticed many countries to consider attracting the wealthy to become their citizens. In attempting to secure injections of capital into their struggling economies, some countries have developed mechanisms to allow rich individuals to gain residence and, eventually, to access their citizenship. While the Caribbean islands of St Kitts and Nevis and the Commonwealth of Dominica have long-running investor citizenship programmes dating back to 1984 and 1993 respectively, ${ }^{4}$ in the course of late 2012 and early 2013, several European states, including Bulgaria, Hungary, Portugal and Ireland, have launched such investor programmes. Then, in May 2013, the crisis-struck Cyprus adopted an investor scheme that opened several routes for individuals to be naturalised on grounds of their economic contribution to the state, provided that they have a clean criminal record and own property in Cyprus. ${ }^{5}$ Finally, in October 2013, Malta introduced the investor citizenship scheme that has attracted the most public and political attention. It is similar to the scheme in Cyprus in that it initially offered citizenship simply in exchange for a pecuniary contribution. ${ }^{6}$ However, due to the pressures of the other EU member states and the European Commission, Malta revised its scheme to include a one-year effective residence condition, ${ }^{7}$ but retained its right to decide on facilitating access to citizenship on grounds of wealth.

While these investor programmes can help ailing economies recover, the very idea of setting a price tag on membership in a community is intuitively disquieting. Given the lack of attention hitherto focused on this important issue within citizenship studies, the primary goal of this article is to lay out three potential explanations as to why we might perceive the different mechanisms of preferential naturalisation of investors as problematic. These three explanations focus on the issues of genuine ties and abuse of rights, merit and equality.

2 See, for instance: Christian Joppke, 'How Immigration is Changing Citizenship: a Comparative View' [1999] 22(4) Ethnic and Racial Studies 629; Rogers Brubaker, Citizenship and Nationhood in France and Germany (Harvard University Press 2009); Maarten P Vink and Gerard Rene de Groot, 'Citizenship Attribution in Western Europe: International Framework and Domestic Trends’ 26(5) Journal of Ethnic and Migration Studies 713.

3 Ayelet Shachar, The Birthright Lottery (Harvard University Press 2009) 166-7.

4 Although there is no statistical information, research suggests that states that run such programmes also include Antigua and Barbuda, and Vanuatu.

5 Scheme for Naturalisation of Investors in Cyprus by Exception on the basis of Civil Registry Laws of 2002-2013 (CY), s 111A, sub-s (2).

6 Act LN 269 of October 2013 that amended the Maltese Citizenship Act, Cap 188 (MT).

7 Act LN 47 of February 2014 that amended the Maltese Citizenship Act, Cap 188 (MT). 
By looking at the notions of genuine ties and abuse of rights, we first examine whether the economic utility of the investment to the state can suffice to override some or all other 'normal' criteria for naturalisation. Then, we look at the preferential treatment of investors in the context of merit-based naturalisation and seek to articulate where the limits of money might lie. Finally, we examine how the investment-based ius pecuniae affects the relationships between the members of the polity and naturalised investors and naturalised investors and other applicants, subject to ordinary naturalisation, in ways that challenge citizenship's fundamental connection to the principle of equality.

In order to approach the above criteria in a systematic way, this article draws a very important distinction between three institutional arrangements governing the naturalisation of investors:

(1) the 'golden residence' programmes, whereby investment generates only residence rights or privileges (the UK, USA, Belgium, Australia, Ireland, Singapore, Portugal, Bulgaria, Hungary, Greece etc.) ${ }^{7 a}$

(2) discretionary naturalisation on grounds of economic interest (as national interest) applied in a number of the world's countries; and

(3) detailed investor citizenship programmes existing in the pure form only in a few countries worldwide.

Hence, rather than being a comparison of how different countries grant naturalisation to investors, ${ }^{8}$ the paper seeks to explain why certain aspects of these programmes intuitively give rise to ethical concerns. To set the issues in context, prior to undertaking the assessment of the various programmes against the three sets of criteria, we first examine briefly some historical and normative aspects of the relationship between money and membership; that is, of the notion of ius pecuniae.

\section{Of money and membership}

Money and property have historically played a central role in the regulation and practices of citizenship. Directly or indirectly, wealth has been connected not only to defining the boundaries of membership, but also to the distribution of rights in a polity. In other words, as much as we nowadays intuitively think of citizenship as a relationship of equality, historically this has rarely been the case. Indeed, drawing boundaries between different groups of people is at the core of the concept so that equality can at best operate between and not across different groups and, very often, pecuniary conditions have been the functional grounds for exclusion of certain groups from membership in a community or from a bundle of rights attached to it.

In ancient Greece and Rome, only free men who possessed property were entitled to the status of citizenship. This, in turn, allowed them to participate in the political life of the community, or, with the development of Roman law, to enjoy an array of rights and receive protection from the polity they belonged to. With the development of feudal systems, the boundaries of citizenship expanded, but became more diversified internally. Property and money became exclusive to feudal lords, a class-defined citizenship community with full access to membership rights. By contrast, peasants, who had limited property and financial resources became a sub-stratum of citizens with restricted membership rights.

7 a Canada discontinued its 'golden residence' programme in 2014, but has announced that it will revise the scheme and reopen it in 2015. A separate Quebec investor residence programme is in place.

8 Jelena Dzankic, 'Pros and Cons of Ius Pecuniae: Investor Citizenship in Comparative Perspective' 14 Robert Schuman Centre for Advanced Studies Working Paper (Robert Schuman Centre 2012). 
Even with the development of modern nation states, money and property continued to play a major role in the context of citizenship. They did not set the boundaries between communities: such lines became defined through territorial and kinship attachments. Rather, they continued to stratify communities of membership from within; that is, financial standing became central to the development and distribution of the key rights of citizenship such as universal suffrage. For instance, from 1848 to 1918 individuals' election rights in Prussia were weighted according to their direct tax revenue (Dreiklassenwablrecht). The population was divided into three classes and the votes of the highest class (constituting less than 5 per cent of the overall population) counted 17.5 times more than the votes of the lowest class (constituting over 80 per cent of the population). ${ }^{9}$ A similar example of how money was used to create internal citizenship boundaries is the US 'poll tax' (capitation). The poll tax was used in the early twentieth century to disenfranchise economically vulnerable groups and African-Americans. ${ }^{10}$ Hence, we see the historical persistence of the link between money and citizenship rights well into the twentieth century.

However, with the development of the modern human rights system, citizenship became increasingly associated with internal equality and with the idea of a 'right to have rights'. ${ }^{11}$ As a consequence, the role of property and money in the distribution of rights within the communities of membership (states) largely faded away. It persisted, however, in the context of drawing boundaries between communities of membership, revealing, once again, that money underpins the exclusionary character of citizenship. This is best seen in the context of naturalisation, where we can observe the modern rendition of the link between wealth and citizenship - the law of money (ius pecuniae).

Naturalisation, or the admission of individuals into the polity, can take different forms. It is commonly based on an individual meeting a set of pre-defined conditions (ordinary), on some kind of pre-existing link with the polity (facilitated), or on merit (exceptional). Ius pecuniae is related to all three types of naturalisation. In broadest terms, this notion has been used to refer to the financial conditions related to naturalisation. ${ }^{12}$ Thus, in terms of ordinary and facilitated naturalisation ius pecuniae refers to the pecuniary criteria for the acquisition of nationality, such as the possession of a steady income or property. ${ }^{13}$ As exceptional naturalisation on grounds of investment entails alleviation of some or a waiver of all of the naturalisation conditions, ius pecuniae refers to the pecuniary contribution, which thus becomes functional grounds for the determination of merit.

Even the modern understanding of ius pecuniae, however, has deep historical roots which show that money could either 'open' or 'close' the doors to membership. For example, ius pecuniae was not unfamiliar in ancient Rome because the wealthy Peregrines (subjects of the Roman empire, but not its citizens) would bribe governors and high officials in order to gain citizenship. The most famous anecdote related to this practice is the one of the Roman centurion who apprehended Saint Paul the Apostle in $60 \mathrm{AD}$ and stated: 'It cost me a large amount of money to become a Roman citizen. ${ }^{14}$ This example clearly shows that the

9 Ludwig Windthorst, 'Speech in Favor of Reforming the Prussian Suffrage, Prussian House of Deputies' $(1873)<$ www.h-net.org/ german/gtext/kaiserreich/windhorst.html> accessed 9 June 2014.

10 Joseph Morgan Kousser, The Shaping of Southern Politics: Suffrage Restriction and the Establishment of the One-Party South, 1880-1910 (Yale University Press 1974).

11 Arendt (n 1) 294.

12 Joachim Stern, 'Ius Pecuniae - Staatsbürgerschaft zwischen ausreichendem Lebensunterhalt, Mindestsicherung und Menschenwürde' in Julia Dahlvik, Hans Fassmann and Wiebke Sievers (eds), Migration und Integration - wissenschaftliche Perspektiven aus Österreich [Migration and Integration - Scientific perspectives from Austria] (Vienna University Press 2011) 55.

13 Ibid 56.

14 Acts 22: 27-8 (NIV). 
pecuniary contribution, even if in the form of what we would presently describe as bribery or corruption, became grounds for the admission of individuals in the Roman polity.

More recently, in the late nineteenth century, the USA had a pecuniary criterion related to immigrants landing at Ellis Island. Upon arrival, immigrants seeking domicile in the USA had to show that they were not 'liable to become a public charge'. ${ }^{15}$ In order to prove this, immigrants were required to show that they could financially sustain themselves and their dependants. While initially the determination of sufficient funds was a discretionary power of the immigration authorities, in 1909, for a few months, ${ }^{16}$ the immigrants had to show that they had a railway ticket to their final destination in the USA and at least $\$ 25$, equivalent to a month's salary at the time. Due to the failure to comply with these pecuniary requirements, many immigrants were sent back to their countries of origin. Their admission was not determined exclusively on grounds of wealth. However, along with other criteria, evidence that an individual had enough money to sustain himself or herself was key to entering the USA.

Nowadays, the majority of the countries in the world have retained some form of income-based naturalisation barriers in their citizenship legislation. For example, in order to become a citizen of a given country, one needs to prove that one has sufficient income, residence, or that one has paid all the due taxes to the state. Income-related barriers of this kind aim at showing the individual's self-sustainability and proving that he or she will not become a liability in the distribution of the public good. By contrast to using money as a barrier to access to citizenship, the discretionary powers of the states in deciding on their membership have turned money into functional grounds for determining whether an individual 'deserves' to be admitted. The logic in this case is that the individual who invests a large amount of money is worthy of becoming a member of the underlying polity, as his or her contribution to the public good (expressed in terms of the financial contribution) is incomparably higher than that of an ordinary citizen. Both of these traits of contemporary ius pecuniae reaffirm the exclusionary characteristics of citizenship and the centrality of money to the conception of membership.

Therefore, there is a historical continuity of the link between money and membership, although it is not a linear and rigid one. Even if in different forms, ius pecuniae has always been central to ius nexi, as it represented the functional grounds for admission to polity and, by extension, to the rights attached to membership. So, if there has always been a link between money and citizenship, and if admitting people into a polity on ground of wealth dates back as far as ancient Rome, why do we intuitively find the idea of 'selling citizenship' wrong?

\section{Normative sources of discomfort with selling membership}

The regulation of the matters of inclusion and exclusion is the prerogative of sovereign states, or the last bastion of national sovereignty. ${ }^{17}$ Yet, as Michael Walzer notes, the state's right to decide on its own matters of inclusion and exclusion is not merely a matter of acting in the world, exercising sovereignty, and pursuing national interest'. ${ }^{18}$ Instead, naturalisation policies rest at the 'core of communal independence' and mirror the 'communities of character, historically stable ongoing associations of men and women with some special commitment to one another and some special sense of their common life'. ${ }^{19}$

15 Ellis Island Website (2012) <www.powayusd.com/online/usonline/worddoc/ellisislandsite.htm> accessed 7 May 2014.

16 Policy suspended after a few months due to pressure from immigrant aid societies.

17 Brubaker (n 2) 180.

18 Michael Walzer, Spheres of Justice (Basic Books 1983) 61.

19 Ibid 62. 
Rather than being a matter at the hands of the state's ultimate authority, the regulation of membership should be reflective of the commitment of the members of the polity to share the burden of and receive the benefits from their membership in a community.

This notion of conceiving demos in the polity in the increasingly transnational communities through the idea of conferring membership to those whose interests are affected by communal decisions is captured by Rainer Bauböck's concept of 'stakeholder citizenship'. ${ }^{20}$ In the context of stakeholder citizenship, all of those whose well-being is related to the future of the community should be recognised as its members. ${ }^{21}$ In other words, a citizenship stakeholder is a person who has a fundamental interest in membership in a particular polity, as opposed to economic or other benefits for which membership may be instrumental. Such individuals can be identified by considering how a person's interest in autonomy and well-being are structurally linked to the collective autonomy (selfgovernment) and well-being (flourishing) of a particular polity. This implies that we cannot think of investors as stakeholders in the community, because they have only an accidental and instrumental interest in citizenship in a state that offers them a favourable investment environment. Equally, in conceiving the demos, Rubio Marin maintains that membership and the full enjoyment of rights should be limited to those who are both resident in and social members of a community. ${ }^{22}$ In this sense 'social membership' can be applied to those already present in and tied to a polity and not to investors who only have the prospect of becoming members while residing elsewhere.

Despite such objections against naturalising investors, grounded on the inexistence of actual stakes in and links to a community, there are still some normative grounds that justify their admission. While arguments such as those underpinning the economic club good theory of citizenship cannot explain why we are uneasy with selling citizenship, they offer explanations as to why states would seek to co-opt individuals who invest money in the polity. ${ }^{23}$ As such, they contribute to our understanding of the state's discretion, which may be a powerful explanation for our concerns regarding investor citizenship programmes.

According to Walzer, in determining their citizenship, states act as 'clubs' and thus have the prerogative to include or exclude prospective members according to their interest. ${ }^{24}$ James Buchanan noted that such interest can be articulated in economic terms and based on a cost-benefit analysis. ${ }^{25}$ That is, polities produce club goods for their members and should therefore select for membership those individuals whose contribution will optimise the production of club goods. According to Buchanan, " $\mathrm{t}]$ he bringing of additional members into the club also serves to reduce the cost that the single person will face'. ${ }^{26}$ This argument also explains the conditions for naturalisation, whereby an individual is often required to comply with certain pecuniary criteria so as to be allowed to become a citizen of a particular state. By contrast, those who are already members of the polity are not required to meet such criteria.

20 Rainer Bauböck, 'Stakeholder Citizenship and Transnational Political Participation: A Normative Evaluation of External Voting' (2007) 75(5) Fordham Law Review 2393.

21 Ibid 2420.

22 Ruth Rubio Marin, Immigration as a Democratic Challenge: Citizenship and Inclusion in Germany and the United States (CUP 2000).

23 James Buchanan, 'An Economic Theory of Clubs' (1965) 32(125) Economica 1; Bruno Frey and Reiner Eichberger, The New Democratic Federalism for Europe: Functional, Overlapping, and competing Jurisdictions (Edward Elgar 1999).

24 Walzer (n 18).

25 Buchanan (n 23) 4.

26 Ibid 8. 
The explanation for this asymmetry of the polity's behaviour towards its members and those aspiring to that status is that only those people whose contribution can help to decrease the shared costs of membership should be naturalised. This also supports Robert Reich's 'idea that the citizens of a nation share responsibility for their economic wellbeing'. ${ }^{27}$ As the operation of markets within the polity entails transactions among individuals, companies, other states etc, in order to maximise their economic security and performance, states seek to ensure that the naturalised individuals will pose no financial burden on their economies.

The same rationale is used to explain why polities would facilitate the naturalisation of investors. According to Bruno Frey, 'the optimal size of a club is reached when the marginal utility received corresponds to the marginal cost induced by an additional member'. ${ }^{28}$ The contribution to the country's economy by the investor is disproportionately higher than the contributions of many of those who are already citizens of a given state. Since the benefits of the investment (such as the boost to the economy, opening of new jobs etc.) vastly exceed the cost of admitting the investing individual to the 'club', the addition of that member would optimise or at least enhance the club's economic performance.

Nonetheless, the purely economic logic behind facilitated naturalisation for investors does not offer an explanation as to why, in using their prerogative to admit individuals, states apply uneven standards even if membership is considered a club good. Joseph Carens claimed that, in behaving so, states act as enterprises rather than as public communities, thus failing to acknowledge the boundary between the public and the private spheres. That is, in the private sphere freedom of association prevails and in the public sphere equal treatment does. ${ }^{29}$ This implies that, in deciding on their membership criteria, states are bound to treat individuals equally.

However, the conventional argument, also highlighted by Carens, is that states have the moral duty to treat as equals only those who are already their members. ${ }^{30}$ There is no requirement for states to treat those who want to naturalise equally with those who are already citizens. Yet, states do have an obligation to treat those who apply for citizenship as equals in the sense of not discriminating in morally arbitrary ways between them. This obligation is, in principle, enshrined in the conditions for naturalisation. However, not all the non-members of the polity are subject to the same criteria for naturalisation and special or preferential naturalisation exists on grounds such as family unity, cultural affinity, civic values, preferential treatment for former citizens, or citizens of certain other countries. ${ }^{31}$ The reason for facilitating naturalisation on bases such as these is premised on the assumption of the individual's pre-existing ties with the aspired community of membership (spouses, children, expatriates, co-ethnics), or humanitarian arguments and international legal obligations (refugees). These circumstances enable states to waive some of the criteria for admission, for instance, by reducing the residence requirement.

A similar logic operates in waiving all other criteria where individuals are offered naturalisation on grounds of national interest, or exceptional contribution to the state. As

27 Robert Reich, The Work of Nations: Preparing Ourselves for 21st Century Capitalism (Vintage Press 1991) 18.

28 Bruno Frey, 'A Utopia? Government without Territorial Monopoly' (2001) 6(1) Independent Review 99, 102.

29 Joseph H Carens, 'Aliens and Citizens: The Case for Open Borders' (1987) 49(2) Review of Politics 251, 269.

30 Ibid (n 29); Joseph Carens, 'Migration and Morality. A Liberal Egalitarian Perspective. Free Movement' in Brian Barry and Robert Goodin (eds), Ethical Issues in the Transnational Migration of People and of Money (Pennsylvania State University Press 1992) 25-47.

31 Kristen Jeffers, Iseult Honohan and Rainer Bauböck, 'Comparing Citizenship across Europe: Laws, Implementation and Impact' (2012) EUDO Citizenship <http://eudocitizenship.eu/docs/CITLAW_explanatory\%20text.pdf > accessed 2 May 2014. 
outlined by Buchanan, the logic of equal treatment is overridden by the asymmetry of gains for the community from an individual's membership. ${ }^{32}$ In countries that allow facilitated naturalisation on grounds of exceptional contribution to the state, rewarding such achievements is recognition of merit rather than of money or class.

For instance, Shachar claims that naturalisation of talented sportspeople reinforces the 'country's collective pride and national reputation'. 33 This is the case because exceptional sportspeople perform openly, in the field, under national flags, a scenario which has often been symbolically associated with battlefields. ${ }^{34}$ Similarly, facilitated naturalisation for scientists or artists can be justified by their public exposure and the ability to win international awards (e.g. a Nobel Prize or an Oscar). Hence, the normative argument for allowing facilitated naturalisation to talented people is that by virtue of their talent and public exposure they instil a sense of collective pride among other members of the polity. That is, they manifest their association to the new polity openly, which reinforces other members' sense of belonging to that polity.

By contrast, even if we think of the ability of the investors to generate income as a particular 'talent' (although many investor citizenship programmes do not question the origins of an individual's wealth), this ability does not entail the same type of collective public exposure as the above-mentioned ones. The investment may enhance the country's economy and create additional job opportunities, but these are understood to be for the sake of the investor, rather than for the benefit of the new polity. In other words, by not acting under national flags domestically and by not winning international prizes and awards that would inspire the association of other members of the polity with the investors' achievements, the latter only have a limited impact on the emotional plane of citizenship collective identification with the state.

Moreover, the admission of investors only on grounds of wealth raises the question of what can be purchased by money, encapsulated in Walzer's argument on what money can and what it cannot buy. ${ }^{35}$ The goods that can be purchased shape the 'sphere of money', which includes 'all those objects, products, services, beyond what is communally provided, that individual men and women find useful or pleasing, the common stock of bazaars, emporiums and trading posts'. ${ }^{36}$ Inherent in this normative definition of the sphere of money are also its limits. That is, the communally provided goods and services that are also at the core of membership in a polity are not available for purchase. As Walzer notes, 'rights are proof against sale and purchase' 37 and, as citizenship entails the 'right to have rights', 38 then the purchase of citizenship should be a 'blocked exchange'39 that limits the dominance of wealth.

In addition to this general observation, two further aspects of facilitated naturalisation for investors represent examples of 'blocked exchanges' ${ }^{40}$ First, naturalising investors by waiving all other criteria equalises financial contribution with cultural, sports and educational achievements. The latter are considered reputational gains 'which are not

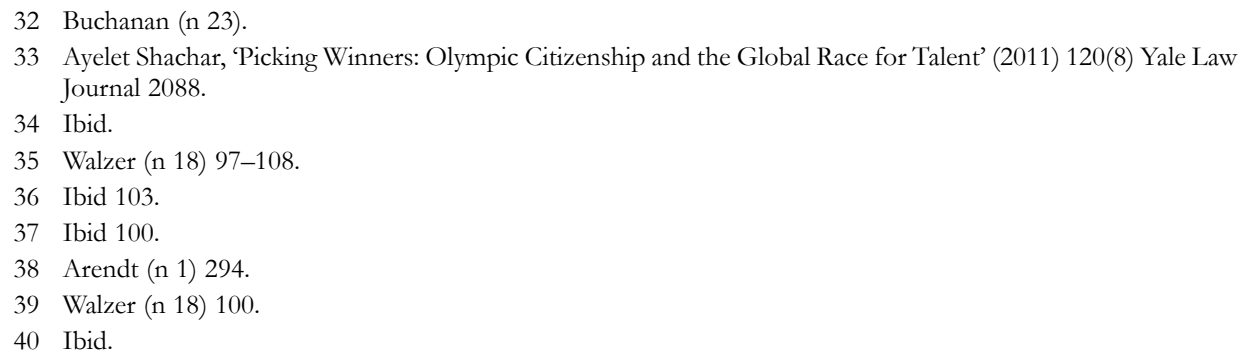


available for purchase' and thus investment violates the sphere boundary of money. ${ }^{41}$ Thus, naturalisation of this kind gives precedence to one social class over others, breaching the sphere boundary of money by 'unlocking' blocked exchanges. It reduces citizenship to a commodity that is traded for money and not based on the actual connection with the state, as is the case in ordinary naturalisation. Second, the discretion in the granting of investor citizenship has caused political controversies in a number of countries. Corruption and secret deals, which have manifestly happened in cases of investor citizenship, violate the sphere boundary of money as 'political power and influence cannot be bought and sold'. ${ }^{42}$ This fact, however, does not imply that naturalising the investor will affect political power by virtue of a single individual's participation in the polity's operation. Rather, the marginal influence of a single vote in a polity will be outweighed by the much stronger concern about corruption of those who have had the discretionary power to decide on the admission of such an individual.

These normative observations help us to generate three possible hypotheses that explain why we are uncomfortable with the idea of selling citizenship. First, our intuitive discomfort with the idea of selling citizenship may be related to the question of whether the pecuniary contribution can be a sufficient link with the polity. In order to assess this, we will look at the notion of genuine ties. Second, the admission of individuals only on grounds of wealth raises the question of whether money is equal to merit, an issue that we will assess by looking at the 'sphere boundary of money'. Third, even if (as explained in the previous section) citizenship has historically been an exclusionary concept, nowadays we think of citizenship in the context of equality; hence our concerns related to the sale of citizenship may be related to the issue of 'equality of membership', assessed in the last section of this paper.

\section{Investor citizenship, genuine ties and the abuse of rights}

A possible explanation for our discomfort with investor citizenship programmes is that, in admitting new members, states generally seek to ensure that there is a connection between the individual and the polity. This is the reason why naturalisation, which in most countries is a discretionary right of the state and not an individual entitlement, is based on a series of conditions. Hence, we may be concerned with the fact that for investors, those conditions are alleviated - or completely waived.

Naturalisation conditions commonly entail the individual's physical link with the state (residence), his or her knowledge of the socio-cultural norms of the polity (language and culture tests), moral standing (absence of criminal record) and financial sustainability (proof of income). However, states may use their prerogative to facilitate naturalisation for some categories of applicants, based on family links, ethno-cultural affinities, special achievements etc. The rationale behind such facilitated naturalisation is the presumption that such individuals already have social ties with the polity. In the context of understanding investor citizenship programmes, these approaches to naturalisation show a discrepant dynamic. On the one hand, states seek to uphold the principle of genuine ties through naturalisation criteria. This implies that nationals are assumed to have a close link to the respective state. ${ }^{43}$ On the other hand, the state indeed has the right to decide on its membership, which may result in the abuse of rights by the respective state. This abuse of rights occurs because the state's reasons for introducing facilitated naturalisation for investors, and not merely the fact of admitting such individuals, affect the quality and legitimacy of the underlying citizenship policy.

41 Walzer (n 18) 102.

42 Ibid 100.

43 Reich (n 27) 1402. 
The notion of genuine ties first appeared in the Nottebohm case, concerning a German national who resided in Guatemala for a number of years after the start of the Second World War and subsequently obtained the nationality of Liechtenstein, a country with which he had only marginal contacts. While the ruling of the International Court of Justice (ICJ) noted that deciding on membership was a prerogative of each sovereign state, it defined nationality as 'a legal bond having as its basis a social fact of attachment, a genuine connection of existence, interests and sentiments, together with the existence of reciprocal rights and duties'. ${ }^{4}$ This 'genuine connection' implies that the individual concerned is 'more closely connected with the population of the State conferring nationality than that of any other State'. ${ }^{45}$

Robert Sloane has criticised the theory of genuine ties as outdated in the context of globalisation, due to the increased migratory flows and the attachments that individuals develop with multiple polities. ${ }^{46}$ Drawing on the legal practice of the ICJ in the area of nationality law, he noted that the notion of genuine ties should be abandoned and that 'the international regulation of nationality should be responsive to the function that nationality serves in context'. ${ }^{47}$ Instead, he proposed the abuse of rights theory as a better mechanism for understanding the state's behaviour, particularly as regards the normative aspects of the state's behaviour. Following Kiss, Sloane proposed that the abuse of rights occurs when 'a State exercising a right either in a way which impedes the enjoyment by other States of their own rights or for an end different from that for which the right was created, to the injury of another State'. ${ }^{48}$ While the injury of another state may or may not occur, and it usually is not the rationale for the adoption of the investor citizenship programmes, we may still argue that changing the purpose of the right the state has in admitting new members is an abuse of rights because the logic behind the right has been altered.

Analysing the granting of citizenship to investors in this context, we can see some problematic aspects of these programmes, particularly in cases where all other requirements for naturalisation are waived. However, these issues are reflected differently in the three institutional arrangements for investor citizenship.

The golden residence programmes have a clear economic rationale based on financial priorities of states. Such programmes often require the investor to relocate to the said country, thus making it the focal point of his or her business activity. Obligatory residence yields both tax revenue and benefits for the recipient country through the multiplier effect of the investment in the state's economy (e.g. creation of jobs, consumption of goods etc.). The investment contributes to the public good, while the investor is bound to reside in the country in order to become a citizen, which also implies the establishment of links between the individual and the community through socialisation (learning the language, culture etc.). The criteria differ not only in terms of the amount of investment required, but also in terms of the type of investment and its effect on the economy. ${ }^{49}$ For instance, countries such as Portugal, the USA and Bulgaria require the investor to create several jobs for the nationals of those countries in order to obtain residence. Other countries base their decision to grant residence on grounds of tax revenue collected from the investment, or offer the investors

44 Nottebohm [1955] 2 ICJ 1, 23.

45 Ibid.

46 Robert D Sloane, 'Breaking the Genuine Link: The Contemporary International Legal Regulation of Nationality’ (2001) 50(1) Harvard International Law Journal 31.

47 Ibid 51 .

48 Alexandre Kiss, 'Abuse of Rights' in Rudolf Bernhardt (ed), Encyclopedia of Public International Law 1 (North Holland 1992) 4.

49 Dzankic (n 8). 
the option of targeting a specific geographical region or a high unemployment area (e.g. the USA, Malta, Bulgaria), sector or industry (e.g. Spain, Portugal, Czech Republic, Bulgaria). Countries such as Cyprus also require the investment to be maintained for a certain number of years. In order to ensure the effectiveness of the investment, these countries have established specific regulation of how the investment should be handled in order to enable the applicants to renew their residence permit after one to two years and eventually to receive citizenship. All of these countries require the applicant to formally register residence on their soil in order to qualify for naturalisation. Investors remain subject to the standard (or slightly facilitated) 50 naturalisation procedure. For the states implementing these programmes, the rationale is to create economic benefits from investment, while conditioning the applicant to establish durable personal and business ties with that country prior to naturalisation.

By contrast, the conferral of citizenship to investors while waiving all other naturalisation criteria is more contentious because the naturalised individual may not claim to have established any links with the state other than the investment. In countries that facilitate naturalisation to foreign nationals on grounds of their exceptional contribution to the country's society, economy, sports, or culture, citizenship laws contain this tension. The global statistics as regards this provision are unavailable, but the data at the European Union Democracy Observatory (EUDO) on Citizenship indicate that out of the 28 member states of the EU, 22 allow discretionary naturalisation on grounds of special achievements. ${ }^{51}$ The degrees of states' discretion range from the powers of the authorities to waive all the ordinary naturalisation conditions to the alleviation of some (e.g. language knowledge, or renunciation of dual citizenship) and retention of others (e.g. residence, oath of allegiance etc.). In principle, exceptional naturalisation is used only in a few cases annually and sometimes the number is limited by law (e.g. not more than 10 people annually in Estonia). ${ }^{52}$ However, the procedure in itself raises moral concerns for the state's actions. In principle, a state seeks to reward those individuals who have de facto made a significant contribution to its economy. Genuine ties, which in cases of ordinary naturalisation are enshrined in language, culture and socialisation (residence) requirements, fade away in light of the state's prerogative to decide upon its national interest.

Equally, in defining 'national interest' in states that implement investor citizenship programmes through facilitated naturalisation, without clear criteria as to the amount, nature and effects of investment, we can attempt to see whether this practice represents a potential abuse of rights. The decision on what constitutes national interest is a discretionary right of the state's authorities. In turn, investment, rather than a clearly stipulated national interest, drives the decision to grant naturalisation, which reaffirms the question of whether the investment alone can guarantee an individual's genuine ties with the polity. As the end of the state's prerogative to decide on its membership alters the meaning of national interest, we may claim that this represents an abuse of rights. However, the logic behind the state's prerogative to decide on its membership through discretion has remained unchanged (i.e. the desire to attract the most competitive individuals in any given field) and

50 1) In cases where residence is generally difficult to obtain; 2) in cases where the ordinary residence requirement is reduced (case-to-case basis).

51 The citizenship laws of Denmark, Finland, Poland, Spain, Sweden and the UK do not contain provisions on naturalisation on grounds of special achievements: EUDO on Citizenship, CITLAW Indicators (EUDO 2013) $<$ http:/ / eudo-citizenship.eu/databases/modes-of-acquisition?p=\&application=modesAcquisition \&search=1\&modeby=idmode\&idmode $=$ A24 $>$ accessed 14 May 2014.

52 Rainer Bauböck and Sarah Wallace-Goodman, 'Naturalisation' (2010) EUDO Citizenship Policy Brief No 2 (EUDO 2010) 2 <http://eudo-citizenship.eu/docs/policy_brief_naturalisation.pdf> accessed 5 June 2014. 
abuse of rights can offer little explanation for our discomfort with such exceptional naturalisation for investors.

This reasoning can also be applied to states that have specific investor citizenship programmes. The rationale behind the investor citizenship programmes in the Caribbean islands is based on the geographical position of these states, their low level of gross domestic product per capita and their lack of competitiveness on the global market. Their national interest is clearly defined in terms of the amount of investment and targeted industries. In this context, we can argue that, given the consistency in the logic and the ends behind these programmes, the abuse of rights on behalf of the state in naturalising investors through such programmes is lower.

Here, it is also presumed that an individual who helps the state to fulfil its defined national interest has established strong economic ties with the new community of membership. However, since the investor is in possession of the citizenship of St Kitts and Nevis, the Commonwealth of Dominica, Antigua and Barbuda and Cyprus, but is not bound to reside therein, his or her level of genuine ties with these polities is lower than that of an ordinary citizen (or a transnational migrant). This is supported by the assumption that physical presence in a country drives individuals to establish social and personal ties and, thus, to relate to the polity as the locus of both their personal and professional activity.

In a nutshell, while both the contested notion of genuine ties and the possible replacement criterion of abuse of rights can offer some explanation as to why we intuitively find the sale of citizenship uncomfortable, this explanation is rather incomplete. Even if we consider that the idea of genuine ties implies not only a physical connection of the individuals with the state envisaged through residence, but also other links such as social and personal ties, as well as the knowledge of the state's language, customs and culture, it is still the prerogative of the state to decide on the grounds for admission. In this context, the notion of abuse of rights can be used to explain the contention in the change of the logic behind the definition of the notion of 'national interest'. However, neither of these concepts fully captures and explains why naturalisation of investors would be more disquieting than that of individuals who made a contribution to the state on grounds of merit other than on economic grounds.

\section{Investor citizenship, merit and the sphere boundary of money}

The question of whether a pecuniary contribution can be equalised to merit and talent is a complex one and could help to understand why we are uncomfortable with the idea of selling citizenship. This issue is manifested to different degrees in the three institutional arrangements regulating naturalisation of investors. Since, in golden residence programmes, the investment facilitates access to one of the criteria for admission (residence) rather than full membership, this contention is not pronounced in such programmes. In detailed investor citizenship programmes and in discretionary naturalisation, the naturalisation of investors is based on national interest.

This national interest is often conceived broadly and left at the discretion of authorities. In order to be granted citizenship an individual should contribute to the state's national interest through 'exceptional achievements'. The idea of exceptional achievements is an umbrella concept, bringing together accomplishments in various spheres of human activity, including economy, culture, science, sports etc. Unlike in the case of detailed investor programmes, there is no clear legal line between pecuniary contribution and other achievements. As a consequence, the reputational gains, which are a matter of talent or merit, are equalised with money, that is, with wealth and social standing. 
To illustrate this, we can use some key examples. For instance, Article 10(6) of the Austrian Nationality Act stipulates that the requirements of residence and single citizenship are not applicable if 'the Federal Government confirms that the granting of nationality is in the particular interests of the Republic by reason of the alien's actual or expected outstanding achievements'. ${ }^{53}$ The corresponding Article 9(2) of the Italian citizenship legislation notes that ' $[\mathrm{b}] \mathrm{y}$ decree of the President of the Republic, having heard the Council of State and following a decision by the Council of Ministers, upon a proposal of the Minister for the Interior, in consultation with the Ministry for Foreign Affairs, citizenship may be granted to aliens where they have rendered an outstanding service to Italy, or where an exceptional interest of the State exists. ${ }^{54}$ In Luxembourg, Article 8 of the country's citizenship law stipulates that ' $[\mathrm{r}$ ] egardless of conditions in articles 6 and 7, naturalisation can be granted in exceptional circumstances to the foreigner of age who is or has rendered exceptional services to the state'. ${ }^{55}$ In each of these illustrative cases 'outstanding achievements', 'outstanding service', 'exceptional interest', or 'exceptional service' may equally refer to talents, which are not available for purchase (e.g. sports, music, art etc.) and to investment, which involves a monetary exchange.

By contrast, in the detailed investor citizenship programmes in St Kitts and Nevis, the Commonwealth of Dominica, Antigua and Barbuda and Cyprus, national interest is encapsulated in the legal provisions on the nature and effects of the economic contribution to the state. The pecuniary contribution is defined as one facet of the national interest, which could also be manifested in other forms regulated through fully discretionary naturalisation. This implies that at least a legal line has been drawn in these programmes separating naturalisations based on money from those based on merit and talent. The contention therefore exists at the level of definition of national interest, for the sake of which citizenship becomes fully commodified when exchanged for money. This commodification implies that membership is tradable for a fixed amount of money as defined in the underlying programmes. The exchange on grounds of merit other than money, as explained previously, can be justified on grounds of the prospective members' public exposure within the community and internationally on behalf of it. Such an exposure helps to reinforce communal bonds of citizenship.

\section{Discretion and discomfort with naturalising investors}

These days, acquisition and loss of citizenship are regulated by laws in order to ensure some transparency in the procedures that regulate the formal belonging to the state. The different programmes that grant citizenship to investors show a different degree of this transparency. The golden residence programmes where investors are bound to meet the ordinary naturalisation criteria are the most transparent ones. The detailed investor citizenship programmes, which give far less discretion to the state's authorities to decide on naturalisation, are more transparent than facilitated naturalisation on grounds of national interest. Therefore, the more regulated the investor programmes are, the less scope do they leave for the violation of the sphere boundary of money and the unlocking of blocked exchanges. ${ }^{56}$

The most commonly raised objections to these programmes have been tax evasion and money laundering. For instance, the (former) US and UK citizens naturalised in St Kitts and Nevis and the Commonwealth of Dominica pay considerably lower taxes in the Caribbean

53 Austrian Nationality Act 1985 (FLG I 37/2006).

54 Act No 123/83 on Nationality (OG 112/1983).

55 Loi du 23 octobre 2008 sur la nationalité luxembourgeoise (Mémorial A - Nº 158 du 27 octobre 2008, Journal Officiel du Grand-Duché de Luxembourg).

56 Walzer (n 18). 
states. A more recent report by the US Department of Treasury has alerted interested parties to the potential abuse of the investor citizenship programmes for money laundering and financial crimes. ${ }^{57}$ The situation with the golden residence programmes is very similar and, in 2012, Eduardo Saverin, one of the co-founders of the social network Facebook, announced that he would take up Singaporean citizenship, a move that would save him millions of US dollars because Singapore does not operate a capital tax policy. ${ }^{58}$

However, countries that do not have a clear economic programme within which the investment is made are faced with a further contentious issue, which has its roots in the state's discretionary powers. The absence of a clear programme raises issues over the discretion of authorities in determining the aptness of an individual for naturalisation, which may result in institutional corruption. ${ }^{59}$ A recent example comes from Austria, where the Carinthian Freedom Party (FPK) politician Uwe Scheuch promised to facilitate the granting of Austrian citizenship to a Russian investor in return for a $€ 5 \mathrm{~m}$ investment in Carinthia and a 5 to 10 per cent donation of this amount to FPK. ${ }^{60}$ This case clearly illustrates the link between preferential naturalisation of investors and the corruption of public officials.

Hence, looking at the notion of the sphere boundary of money in the context of merit helps us to understand that certain achievements are not available for purchase and that programmes based on pecuniary contribution as grounds for naturalisation have the potential to generate corruption. Even so, we cannot claim with certainty that corruption exists in all investor citizenship programmes as examples are scarce, which limits the explanatory potential of this assumption for our belief that it is wrong to sell citizenship. Indeed, while these programmes offer a broader scope for corruption of public officials, such instances may also occur in other types of naturalisation.

\section{Investor citizenship and the equality of membership}

Liberal ideas about equality imply that all members of the polity should be treated in the same way despite their social standing, wealth, or class. Yet, the question that arises from investor citizenship is whether those who are not members of the polity should also be treated equally. In fact, there is no obligation for the state to do this apart from general provisions requiring non-discrimination between citizens and non-citizens on grounds of race, ethnicity and religion. ${ }^{61}$ However, while the state has the prerogative to decide on its membership and, thus, it is indisputable that it can choose from among those who apply to be naturalised, the process of granting a foreign national citizenship of a given state is normally accompanied by the person's fulfilment of certain criteria. In classifying these criteria, we can distinguish between ordinary and special naturalisation. As explained in the previous section, special naturalisation, whereby some of the requirements are waived for the applicants, is based on pre-existing ties that the applicants have with the polity or for

57 US Department of Treasury, Advisory: Abuse of the Citizenship-by-Investment Program Sponsored by the Federation of St Kitts and Nevis FIN-2014-A004 (20 May 2014).

58 Susanna Kim, 'Facebook IPO: Eduardo Saverin Defends Citizenship Move' ABC News (2012) <http://abcnews.go.com/blogs/business/2012/05/facebook-ipo-eduardo-saverin-defends-citizenshipmove/ > accessed 2 June 2014.

59 Laura M Johnston, 'A Passport at Any Price? Citizenship by Investment through the Prism of Institutional Corruption' 22 Edmond J Safra Working Papers (Harvard University 2014) <http://ssrn.com/abstract=2324101> accessed 11 May 2014.

60 'Citizenship not for Sale, Minister says on "Corrupt Scheuch" Claims' Austrian Times (2011) <www.austriantimes.at/news/General_News/2010-01-21/19891/Citizenship_not_for_sale,_Minister_says _on_'corrupt_Scheuch'_claims > accessed 16 May 2014.

61 International Convention on the Elimination of All Forms of Racial Discrimination 1963, Article 1. 
humanitarian reasons. In such cases the state applies the norm of adequate or proportionate requirements. By contrast, investor citizenship programmes allow facilitated admission into a polity to a group of people only on grounds of their wealth and social standing, while some or all of other conditions are waived. This indicates that there is a tension between the philosophical postulates of citizenship and the naturalisation policies that the states actually apply. As Laura Johnston noted, 'the act of exchanging a higher-value good (citizenship) for a lower value good (money) destroys the value of citizenship and corrodes public trust in that institution in a way that naturalisation on other bases does not'. ${ }^{62}$ Yet, as there are different ways of regulating investor citizenship, the degree of this ethical issue of ius pecuniae varies across countries.

In states implementing golden residence programmes, investors are commonly bound to comply with other naturalisation criteria including residence and language requirements. In countries where dual citizenship is not allowed, these individuals are also required to relinquish their citizenship of origin. The golden residence programmes in Singapore, Hong Kong and Monaco are good examples of this. ${ }^{63}$ In this respect, golden residence programmes can be said to generally uphold the equality of access to citizenship. Exceptions to this may occur in countries, such as Romania or Portugal, where, respectively, the state authorities have the right to reduce the residence requirement by a few years for naturalisation of those individuals who have obtained golden residence on grounds of investment, or to allow investors to maintain residence while living elsewhere. ${ }^{64}$ In these cases, even though investors are still subject to residence and other criteria, the fact that the actual requirement for naturalisation is facilitated only on financial grounds disrupts the equality principle. However, this contention is significantly lower than in countries offering facilitated naturalisation to investors or applying detailed investor citizenship programmes.

In the latter, authorities have discretion in deciding on national interest and exceptional achievements, thus singling out one social class over others. This challenge to equality exists both in states allowing the facilitated naturalisation to investors only through discretion and in those implementing detailed investor citizenship programmes. For instance, in St Kitts and Nevis the residence requirement for ordinary naturalisation is 14 years, while naturalised investors are not subject to any residence requirement. The approaches taken in the Commonwealth of Dominica, Antigua and Barbuda and Cyprus are similar. These three states have residence requirements of five, seven and seven years, respectively, for ordinary naturalisation. In these cases there is also no obligation for those who obtain citizenship by investment to live in the country.

A further contested aspect of investor citizenship in relation to the equality principle is wonderfully captured in a phrase from George Orwell's Animal Farm whereby 'all animals are equal but some animals are more equal than others'. ${ }^{65}$ Provisions stipulating the discretionary right of states to offer citizenship to foreign nationals often waive the requirement for the person in question to relinquish their citizenship of origin. This fact confirms the 'special status' of such individuals in the states in which they have been naturalised. In states that forbid dual citizenship, the principle of equality is disrupted because extraordinarily naturalised persons are able to retain their nationality of origin

62 Johnston (n 59) 5.

63 Christian H Kälin, Global Residence and Citizenship Handbook (Ideos Publications 2013) 195-8.

64 In Portugal, instead of actually being present in the country continuously, as is required from ordinary applicants, the investor is required to spend one week in the first year and two weeks in each subsequent year in order to maintain his or her residence rights.

65 George Orwell, Animal Farm (Secker \& Warburg 1956) 112. 
unlike ordinary citizens. The latter would normally lose their citizenship of origin should they seek to become naturalised in another country.

As in the case of the disruption of the equality principle in the process of naturalisation, the equality within the polity is sustained to varying degrees in different types of investment-based naturalisation. Golden residence programmes generally uphold the equality principle as they require the applicant to renounce his or her citizenship of origin if that is required by the country's nationality legislation. By contrast, countries offering citizenship to investors through discretionary naturalisation or detailed programmes do not require renunciation of the citizenship of origin and as such challenge equality of membership.

Therefore, equality of membership can offer the best explanation as to why we intuitively red-flag investor citizenship programmes: we consider them a potential threat to democracy, a challenge to equality and a mechanism of commodifying citizenship. ${ }^{66} \mathrm{By}$ transforming citizenship into a good with which both states and investors seek to optimise their performance, investor programmes clearly infringe upon the liberal ideas of democracy. They shake our understanding of membership in today's states as 'communities of character', 67 in which we presume that an individual cannot be granted privilege merely on grounds of wealth, as has historically been the case with citizenship. In other words, the very paradox contained in the history of citizenship, whereby both membership and rights were related to property and thus generated an unequal treatment of individuals by the state, re-emerges in the context of investor schemes. Hence, our intuitive concerns about the sale of citizenship emanate from our perception of equality in modern democracies, which we believe has transcended the idea that the distribution of rights is inextricable from wealth and social class.

\section{Conclusions}

The sale of citizenship raises many concerns which make us uncomfortable with the idea of approaching community membership as a tradable commodity. By exploring the different approaches of countries to this type of facilitated naturalisation, this paper has argued that the most plausible explanation for our discomfort with investor citizenship emanates from our ideas about contemporary citizenship as a community of equals. The precedence of wealth and social class, in fact, reveals our sensitivity to the equal distribution of rights among individuals that we believe lies at the core of citizenship. This explanation offers a deeper insight into the problematic aspects of different investor citizenship schemes than genuine ties and the abuse of rights theories, or the notion of the sphere boundary of money, both of which fail to capture the tensions within the concept of citizenship.

In fact, investor citizenship programmes highlight the paradoxical nature of citizenship, which does not only entail the idea of equality and 'the right to have rights' 68 but also has an exclusionary character. This exclusion, which has characterised membership in a community ever since the Greek polis, has historically been related to money and the possession of property. An insight into the history of the concept has revealed that the rights attached to citizenship were related to ius pecuniae. In other words, individuals who possessed money and property were granted a far greater array of rights than those who did not. While modern citizenship, based on 'stakeholding' ${ }^{69}$ (membership in a community with

66 Stern (n 12).

67 Walzer (n 18) 62.

68 Arendt (n 1) 294.

69 Bauböck (n 20) 2420. 
a contribution towards its future well-being), assumes equality, investor citizenship programmes distort such an idea on two grounds. First, in terms of access to membership, they reveal the exclusionary character of citizenship. Investor citizenship programmes show that the membership boundaries are permeable to money, which effectively commodifies citizenship. Second, in terms of rights, investors are granted privileges, such as dual citizenship, which cannot be enjoyed by ordinary citizens. That is, investor citizenship programmes invoke inequalities based on wealth that we thought had disappeared with the coming of modern states.

These tensions could not be fully captured by the notions of genuine ties and the abuse of rights in the context of national interest, even though they offer some explanation for our discomfort with certain types of investor schemes. For instance, they help us to understand why facilitating access to citizenship to investors while retaining other criteria (golden residence programmes) creates the least contention. In countries such as the UK, Spain, Hong Kong, the USA etc, the investment is not the grounds for citizenship. It merely facilitates the individual in meeting the residence criterion for naturalisation and applicants are required to undergo an ordinary naturalisation procedure. This indicates that in these countries there is an emphasis on the establishment of a genuine link between the applicant and the polity. The issue, however, in countries that waive the ordinary naturalisation requirements is more complex and evokes the abuse of rights principle. Neither the countries implementing detailed investor citizenship programmes nor countries that have provisions for discretionary naturalisation on grounds of investment uphold the genuine ties. Rather, they change the logic behind national interest so that it includes investment, which effectively represents abuse of rights, even if such an abuse is not directed towards another state. Even so, genuine ties and abuse of rights have limited explanatory potential for our understanding of facilitated naturalisation in general (i.e. why states grant preferential access to certain groups, such as spouses, ethnic kin, diaspora etc.) and of meritbased naturalisation in particular.

Hence, the second theory that we used to try to understand the tensions underpinning investor citizenship programmes was that of the sphere boundary of money. The argument presented in this paper established that investor citizenship represents a violation of the sphere boundary of money not least because citizenship should not be granted on grounds of wealth and social class and thus reduced to a commodity that can be bought and sold. Rather, countries that have general provisions for facilitated naturalisation on grounds of exceptional contribution to the state equalise the 'economic' (i.e. pecuniary) contribution with reputational gains. Moreover, countries that implement investor citizenship programmes and offer a degree of discretion to their authorities open up the scope for institutional corruption and bribery, as exemplified by the case of corruption in Austria. Despite the fact that corruption represents a further violation of the sphere boundary of money, these programmes only increase the potential for such activities, but are not necessarily characterised by them. This means that looking at what money can buy does not fully explain why we are uncomfortable with selling citizenship.

Hence, we finally turned to the analysis of the notion of equality of membership. In this respect, the study argued that investor citizenship programmes represent a breach of the equality principle both between the prospective applicants and between the naturalised investors and ordinary citizens. However, the degrees to which the equality principle is disrupted varies and is the lowest in countries that naturalise investors through golden residence programmes because there individuals are a) subject to ordinary naturalisation criteria and b) required to relinquish their citizenship of origin. While the Caribbean islands and Cyprus breach the equality principle only with regards to naturalisation as investors 
need not fulfil other naturalisation requirements, they also allow ordinary citizens to retain dual citizenship and thus sustain the equality principle within the polity. On the contrary, those states that facilitate naturalisation of investors through the discretion of the authorities challenge the equality principle on both counts, provided that they forbid dual nationality for ordinary citizens. Therefore, the insight into the principle of equality of membership revealed the most tensions that surround investment-based naturalisation schemes and can best explain why we do not like the idea of selling citizenship: not because the investors do not live in the respective country as ordinary applicants do, or because money is not equal to merit, but because we perceive that ius pecuniae disrupts the equality of membership merely on grounds of wealth and social class. 